\title{
Right to Education using Human Rights Based Approach: A Policy Perspective for India
}

\author{
Mamta Viswanath \\ Ph.D. Research Scholar, Dept. of Politics and Public Administration, University of Pune, Ganesh Khind, Pune, \\ Maharashtra
}

\begin{abstract}
This paper takes a look at Indian education policies and underscores the urgent need for a human rights approach. Though the Indian constitution gives its citizens the fundamental right to education with effect from $1^{\text {st }}$ April, 2010, whether the requirements of a rights based approach have been met is yet to be seen. Secondly, the paper will briefly analyze the present status of right to education in India to understand the drawbacks at policy level and identify the factors responsible. Thirdly, the paper will highlight the ways in which a rights-based approach can be adopted at the implementation level. Inspiration can be drawn from various countries which have given right to education to their citizens and are nearing universalization of elementary education. The right to education can be fully realized only if it is implemented with a concerted rights-based approach to education.
\end{abstract}

Keywords: Human rights, right to education, elementary education, public policy

\section{Introduction}

The strides made towards development by India in sixty years lifespan have been commendable. It is universally accepted that education contributes to the progress of a nation. But as India is a land of paradoxes, despite the overall progress the education system has been plagued by vicious ills producing unemployable graduates, directionless policy-making, poor performance, exclusionary, discriminating against the poor, marginalized and especially the girls (Guha R, Hindustan Times, 31 Mar 2005).The Indian education system under the British rule had been primarily based on the truancy model. This should have changed after independence but did not on account of various reasons. It is clear that the system has failed in levelling the Indian society, in fact has helped in widening the chasm between the haves and the have-nots. The state is glaring at the greatest challenge in the form of poverty, hunger, malnutrition and unemployment-all pointing towards the urgent requirement of addressing these issues with the tool of education. For effective educational reforms inspiration can be drawn from the experiences of developing countries like South Korea and Bangladesh. South Korea invested first in primary education sector; in 1970's it spent four-fifths of education budget on basic education. Later as per requirement investment on secondary education was increased. This proved to be a good rationale and led to educational development. The government followed the strategy of implementing the right policies seamlessly (Tomasevski, 2001: 15). Bangladesh implemented school incentive programmes paying the children so that they attend school. Poor families were given wheat as an incentive while the girls who attended secondary school were paid a cash stipend. Their parents were also made to promise not to marry off them before the age of 18 years. These incentives had positive impacts and reduced child labour (Kuenningand Amin, 2005, p 8).

Vast majority of countries have signed up and ratified UN conventions on the Rights of the Child and 76 countries give full constitutional guarantee to the Right to Education, 29 countries give partial constitutional guarantee to the Right to Education (Tomasevski, 2001: 18). Many countries have provided legislative and administrative frameworks to ensure that these rights are realized in practice. Most of the countries giving constitutional right of education have followed the strategy of enacting official legislation first and then follow it with actual reforms. A good example of this strategy is Mexico. On the other hand, some countries like Nicaragua implemented important changes to reform school governance with hardly any legal framework. Both of these strategies have benefits and shortcomings (Gershberg, 1995). According to the political setup and social conditions of the country a specific approach to educational reforms may be adopted. Another example of right to education guaranteed by constitution is South Africa (1996, Constitution), section 29 (Berger, 2003). So far, in India educational reforms have been made without a legal framework. With the right to education legislation a much needed legal framework is drawn up. Developed countries like Japan and the USA have a strong public /common school system. India stands to lose if we further ignore the Common School system which should be funded by the government. This would need a policy with utmost care so that the poorest of poor are able to realize the right to education. The Right to Education Act, 2009 does provide for a neighbourhood school but 
aspirations can become reality only with implementing the act in the true spirit and progressively work towards a rights based school system.

In modern times education determines living standards and people without access to education and knowledge cannot make two ends meet, leave alone live a life of dignity. According to the 2011 census though the literacy rate has risen to $74 \%$, a major proportion consisting of 320 millions of Indians remain illiterate. Not only this, gender discrimination persists with a literacy gap of $17 \%$ and a falling sex ratio, from 927 girls to 1000 boys in 2001 to 914 girls per 1000 boys in 2011 (Education World, 2011). These figures show a grim picture of the nation and the lackadaisical approach of the government policies -development policies and education policies in particular. It is important to understand why even in 60 years of long time the governments could not fulfil the promises made by various education policies. Mostly, these policies have been institutional and incremental in approach. The present dilemma however demands a complete overhauling of the education system-a policy which is more rational, a policy that is based on a human-rights model. A rational policy is required for maximizing social gain and a rights-based approach is required so that it is beneficial to the poorest of the poor.

\section{Methodology}

This study undertakes evaluation of education policies and reforms in India with the formulation of Right to Education bill in 2005, the legislation and implementation process of the samefrom ${ }^{\text {st }}$ April, 2010.The focus remains on how the Right to Education is being implemented and what qualitative changes it would bring in the education system. Field work was conducted in Pune city and Guwahati metropolitan area schools through a series of interviews, surveys, data gathering and direct observation. Data was gathered regarding present status of schooling, implementation of right to education in the last one year, shortcomings and possible positive outcomes. Further, a theoretical linkage with Human Rights Approach to the Right to education was made using literature surveys.

\section{History Of Indian Education Policy-Making}

There were various programmes and policies towards education in India in the period spanning between 1948 to the Right to Education Act 2009 being made legal and enforceable on $1^{\text {st }}$ April, 2010. The education commission headed by Dr.Kothari (1964-68) and the subsequent National Policy on Education 1968 was the first official policy signalling the Indian government's commitment to elementary education. Most important issues taken up by the policy were establishing a Common School System to strengthen access to education and pave the way to a socially cohesive nation. However, lacking a detailed strategy, legal force, financial and organisational support, the policy could not be properly implemented. A major breakthrough was made with education being placed in the concurrent list in 1976. The central government assumed a greater role but no positive changes were evident in the education system.

A review of the status of education system was undertaken by the Ministry of Education along with the National Institute of Educational Planning and Administration. This resulted in the National Policy on Education, 1986, which laid stress on the goal of universalization of primary education. Schemes like Operation Blackboard and District Primary Education Programme have not been successful owing to provision of low quality facilities, ineffective transition of curriculum and lack of adequate funds (Jain, 2008). Also, it introduced the menace of non-formal education in India. In 1990, Acharya Ramamurti committee reviewed the National Policy on Education 1986 resulting in a revised National Policy on Education 1992. For the first time, a recommendation to include Right to Education as a fundamental right in part III of the Constitution was made but not implemented (Aradhya and Kashyap, 2006).

Sarva Shiksha Abhiyan was approved by the union government in November 2000 and laid emphasis on achieving the goal of Universalization of Elementary Education through time-bound integrated approach. A new partnership was evident between the centre and the state governments. Most of the existing programmes were absorbed in this Abhiyan with district as the unit of planning. Though Mid-day meal schemes improved enrolment rates, the quality of education remained poor. This policy was criticized as being anti-poor and worked to de-legitimise the government school system as various cost-cutting measures like multi-grade teaching and Para-teachers were used (Aggarwal, 2005). Reasons for poor policy performance as well as policy dilution leading to the dismal educational attainments are many and can be summarized under the following heads.

1. Old and irrelevant Truancy Model of Education System. This system dates back to the pre-independent colonial times where provisions were made to monitor and punish defaulting children and parents. In the whole process the cause for truancy is not tackled with as the state/government does not accept the responsibility to redress the root cause of truancy, which is poverty. This served the interests of the colonial rule but Indian governments, even after independence have continued to allow the outdated system which was concerned with 
monitoring attendance rather than providing enabling environment to realize universal primary/elementary education by tackling problems of child labour, child marriage, inadequate housing facilities, malnutrition, unemployment etc. As the National policy on education 1968 was the first official policy on education, the system continued to suffer from the ills of the outdated system and educational practices (Aggarwal, 2011: 453).

2. Incremental approach to policymaking. In this approach the existing programs and policies are considered as a baseline and the new programs or policies just increase provisions, decrease or modify the current program. The gradual increase in investment in school education through inputs like opening new schools, strengthening the infrastructure, providing mid-day meals has not brought about desired results (Hanushek, 2003). This approach is adopted to play safe and not risk major policy level changes which might require heavy investments or institutional reforms.

3. Inadequate data gathering and information. When the planners and policymakers do not gather required information they cannot assess the situation very well, neither can they relate education to issues like social transformation, development and human rights. Piecemeal approaches like Operation Blackboard, District Primary Education Program, Sarva Shiksha Abhiyan can only bring marginal improvements whereas the requirement is of changing the orientation of the system backed by inputs from teachers, parents, scholars, academicians, along with the experts and bureaucrats.

4. Poor Resource Allocation. In absence of adequate financial support the education system cannot expand, be accessible to the masses and improve upon education quality. The government statistics show that between 1951 and 1955, public expenditure on education was less than $1 \%$ of the total GDP of India (GoI, 2000-2001). In 1976 though education was made a concurrent subject the central government gave no priority to education and continuously invested a less than $3 \%$ of the GDP. Till date no central government has been able to allocate $6 \%$ of the total GDP of India promised by different central governments so very often. Sarva Shiksha Abhiyan is heavily criticized for being anti-poor and delegitimizing the government school system through cost-cutting measures like Multi-grade Teaching and employing Para-teachers (Aggarwal, 2005).

5. Disparity between Requirement and Provisions. In 1964, after a comprehensive analysis of the education system built by the British and understanding the aspirations of the masses, Dr. Kothari recommended a Common School System. This was to strengthen the government schooling and level the diverse society. These recommendations were never implemented. The recommendation of Acharya Ramamurthi committee in 1992 of implementing Right to Education as a fundamental right also met with the same fate. Instead we have had programs funded by the International Monetary Fund (IMF), the World Bank and policies dictated by market forces. As a result the government schools have deteriorated but the private schools charging heavy fees in the form of capitation fees and donation have mushroomed. These schools serve exclusively the rich and the poor are left at the mercy of non-functioning government schools.

6. Mismanagement and corruption in institutions. Beginning with fake registrations of buildings, overestimation in works and construction, to projecting inflated figures of enrolment for financial-aids or salaries of the teachers, the list for corrupt practices is a long one. Also unmindful wastage and pilferage in midday meal provision, multi-level teaching, and Para-teachers work against the poor. The people lose trust in government schooling system. Instances of overloaded teachers, employing a high school pass-out to teach students for a lowly salary also abound.

7. Lack of Political Will. A reputed social activist, in his study of annual national budgets remarks that during 1951-1961 the provision of article 45, which read as, ' the state shall endeavour to provide, within a period of 10 years from the commencement of this constitution, for free and compulsory education for all children until they complete the age of 14 years', lay under a lid; there was not to be found a passing reference to education let alone to article 45 in the budget speeches (Jain, 2008). This shows the neglect of governments quite clearly. Later in 1976, education was removed from the state list and placed in the concurrent list so as to give the central government a bigger responsibility in providing education to the masses. With this also no notable change took place in the education scene; the literacy rate was only $52.21 \%$ in 1991 (Sripati and Thiruvengadam, 2004). Even the Right to Education could be enacted as the fundamental right after 16 years of delay as in 1993, the Unnikrishnan judgement made education a fundamental right but the legislation to this effect came through in 2009. The political parties know that elections cannot be won by promoting education so they are least interested in planning and funding for education policies. 
8. Public apathy and inaction. People in India galvanize into action when it is an issue of poverty, religion, language, and region as is seen during elections. In absence of awareness and education, issues of welfare like health and education continue to be neglected even by the public. Lack of political voice of the poor and illiterate and utter disregard by the intelligentsia maintains the status quo. The governments continue to adopt cost-cutting measures like multi-level teaching and employing Para-teachers in absence of serious concern and public demand for expansion in schooling system. When it comes to implementation of policies, the local politics interferes and directs the process. The pressure groups have not been as persuasive and proactive at the stage of policy making as that of implementation. This result in local political interests and pressures to direct the policy process and the target groups do not get benefit (Subbarao and Raney, 1995).

\section{Education As A Human Right}

Covenant on Economic Social and Cultural Rights, 1966[ICESCR] [Articles 13 and 14], UNESCO Convention, the Convention on the Elimination of All Forms of Discrimination Against Women, 1979 [CEDAW] Article 10, the Convention on the Rights of the Child,1989 recognize education as a human right. A human right is a right a person acquires, is entitled to, which a person can claim just by the virtue of being a human. Human rights are universal, that is, same all over the world, belong to all human beings when they are born and cannot be taken away by anyone (state or individual). Also, human rights are non-discriminatory and are the basis of principles like freedom, peace and justice (RTE Project, http: Ilwww.right-toeducation.org/node/233). Whenever a human right is violated the victims cease to live a life of dignity. According to D'Engelbronner Kolff, human rights are the rights and freedoms inherent in human beings by virtue of their humanity. These are not given to them by rulers, are not earned or acquired by purchase. According to Branson, human rights are not a recent discovery, a passing concern or a short-lived issue. It is also not limited to the modernized western world, is not a new morality or a religion. These are claims which can be asserted, are not related to any institution nor charity. Along with being pious aspirations and moral assertions human right are also legal claims. According to Singh, human rights are the ideals for a democratic government as given in the Universal Declaration of Human Rights in 1948. These are also value expressions relating to human beings by virtue of their humanity and are normative ideals of human life. According to Gewirth, human rights are supremely important and central to all moral considerations. They can be justified by moral principles and are necessary for human actions.

Right to Education has been recognized as a human right as far back as in 1948 with the Universal Declaration of Human Rights. More than 776 million adults in the world are illiterate (Taylor, ActionAid). All these people who did not get education have been violated and Right to Education is the tool through which these people can raise their voice and claim their right from their respective governments/states. The Right to Education is also an obligation on the governments which can be held accountable in case of violation .Also, the Right to Education is a right helping people claim; realize their other social and economic rights. Education strengthens people's social position by increasing their knowledge, skills and confidence to deal with the government agencies (Millan, ActionAid). According to the Amman Affirmation, the Right to Education is a right to participate in a meaningful life of the modern world through education. According to Katarina Tomasevski, the former UN Special Rapporteur on the Right to Education, to be meaningful, education must be available, accessible, acceptable and adaptable.

Along with the Universal Declaration of Human Rights, the Right to Education is recognized by several international conventions like the International Convention of the Rights of the Child (CRC).Various regional human rights instruments also recognize and guarantee the Right to Education. Some of these are the American Declaration of the Rights and Duties of Man(Article 12), the European Convention on the Legal Status of Migrant Workers(Article 14 and 15) and The African Charter on Human and People's Rights(Article 17).

\section{Right To Education In India}

The Indian constitution guarantees a number of human rights to its citizens and education found place in part IV, Directive Principles of State Policy. Education was not a fundamental right and so not enforceable in a court. It was left at the will and financial capacity of the states to make education policies. Later in 1976, education was removed from the State list and placed in the Concurrent list so as to give the central government a bigger responsibility in providing education to the masses. But it was only after the Supreme Court's Unnikrishnan judgement in 1993 that education was to be understood and seen in the context of the right to life and the right to equal opportunity of work already given by the Indian constitution. The judgement held that 'though right to education is not stated expressly as a fundamental right, it is implicit in and flows from the right to life guaranteed under Article 21'Right to Education is a human right and should be read with the right to life, right to equal opportunity of work etc. It is connected with right to life because education enables a person to lead a dignified life. Similarly, it is connected with right to equal opportunity of work because with education people become aware of other rights and can understand and claim their right to equal opportunity of work. 
This judgement gave the power in people's hands and they could claim free and compulsory education. Slowly pressure was built on the parliament with PILs (Public Interest Litigation) being filed in different high courts to enforce the judgement. In 1997 July, the $83^{\text {rd }}$ Amendment Bill was introduced in the Rajya Sabha to make Right to Education a fundamental right but could not be passed due to change in the governments and lack of necessary political will. In 2002, the bill was passed as the $86^{\text {th }}$ Constitutional Amendment Act. After several failed attempts in 2005 and 2008, finally the Right to Free and Compulsory Education Act was passed in 2009 and came into effect from $1^{\text {st }}$ April, 2010. Now under the Indian constitution, article 21 reads 'every child between the ages of 6-14 years has a fundamental right to education which the state shall provide in such manner as the state may by law determine.' The change of education from a directive principle to that of a fundamental right can be seen as India's concern and commitment for at least elementary education (Aikara, 2004). The State Cabinet of Assam unanimously approved the RTE Act on $6^{\text {th } J u l y 2011(T h e ~ A s s a m ~ T r i b u n e, ~}$ Guwahati, and 6th July,2011).

\section{Critical Appraisal Of The Right To Education Act, 2009}

Even after 60 years struggle, the Right to Education becoming a fundamental right is a matter to rejoice. On the other hand, the biggest question is whether this delayed legislation would be able to fulfil the aspirations of millions of Indian citizens deprived of educational opportunity and so relegated to a life of poverty and ignorance. As a fundamental right under the Indian Constitution, the Right to Education has become a justiciable right. It means that people can seek judicial remedy if the government violates their right by not providing access to education, by not providing enough schools and the infrastructure needed for imparting basic elementary level education. It is also clear that now the governments (central as well as state) are bound to make education a priority and provide adequate financial and administrative framework to support education system. For the first time in Indian history a reservation of $25 \%$ seats at first standard level will be made for the poor and the disadvantaged. It means that caste politics will now take a backseat and the poor will be served in the true sense of the term. The Common National Curriculum Framework will work positively to bring all students at par and also improve national cohesion. The provision of School Management Committees is another step towards increasing people's participation and accountability on the governments and teachers part.

On the flip side the RTE Bill has been severely criticized for its shortcomings, the first being the age of the child. The Bill limits the right to ages 6-14 years whereas India as a signatory to the UN Child Rights Convention, accepted the international definition of a child that is upto 18 years of age. By this omission the bill ignores the needs of 0-6 years' age group of children which is a formative stage and also of the age group of 1518 years, which is laughable as at 14 years of age, the child would hardly be in the $9^{\text {th }}$ standard. It may happen that after 14 years, the child would be forced to take up labour work as his education cannot get him/her a decent job anywhere. Thus, the problem of child labour remains unsolved. The 'free schooling' needs broader definition as studies show that it is not just tuition fee /school fee but other expenses such as stationery, uniform, shoes etc. which become a barrier to access to education for the poor. Teachers have criticised the provision of automatic promotion upto $8^{\text {th }}$ standard as this cannot ensure learning. The concept of neighbourhood school is also subject to the government's interpretation and not exactly refers to the immediate neighbourhood of a child. These schools cannot be expected to serve the masses and bridge the social gap as could be done by the common school system. At the best, it is a half-hearted approach towards the public schools fully funded by the government. These provisions are not positive and make the right to education more of a right to schooling with issues of quality education still getting side-lined.

A year after the RTE Act came into effect the first report was released by Kapil Sibal, the Union HRD minister(Kumar, 2006). The report states that only five out of 28 states have notified rules for the implementation of the Act. Also, 8.1 million children in the age group6-14 years are still out of school. There is a shortage of 508,000 teachers all over India. According to Ambrish Rai, spokesperson of the RTE Forum, as the first year did not see implementation of various important provisions of the RTE Act, the onus is on the public and the civil society to build pressure on the government to ensure proper implementation.

\section{Need For A Human Rights Approach To Education}

According to Nelson Mandela, education is the most powerful weapon that can be used to change the world. Importance of education was highlighted way far back by Plato in 'Republic' and since then most of the countries have made some basic education as compulsory to all. Education makes people informed and helps them make collective demands for better social services, governance, effective and equitable use of public resources. Education also helps in alleviating poverty and child labour. With education the poor can effectively combat social ills like class and caste discrimination (EducationWorld,2011). None of the developing countries have achieved the goal of universalization of elementary education without the state taking primary responsibility and providing financial and administrative support needed for the same. Krishna Kumar, former chairman, NCERT (National Council for Educational Research and Training) says that India has been reluctant 
to take this primary responsibility as our society does not regard children a collective responsibility. In fact, children are looked upon as parental responsibility. Nobody is ready to understand that when children do not go to school, the nation loses (Kumar, 1998).

Traditionally, that is, since the British occupation till almost 1990's the education system was based on the truancy or the policing model. It monitored attendance and penalised the truants, that is, the students and their parents. This is in direct contrast with and opposed to a human rights approach as the assumption is that the poor are not willing to send their children to school (Aradhya and Kashyap, 2006). Based on this flawed assumption, provisions are made to monitor and punish defaulting children and parents. In the whole process the cause for truancy is not tackled with as the state/government does not take upon itself to redress the root cause of truancy, which is poverty. So all these long years the Indian governments were concerned with monitoring attendance rather than providing enabling environment fit to realise universal primary/elementary education by tackling problems of child labour, child marriage, inadequate housing facilities, malnutrition, unemployment etc.

With the liberalisation of Indian economy and opening up of the market to private players in 1990's, the education system also witnessed significant changes. The education system developed the traits of a business model or the market approach with the springing up of numerous private schools where education is a commodity for sale; charging high capitation fees, donation and paid seats. Decision-making rests in the hands of a few powerful people excluding the parents, teachers, students and community members. The classrooms are crowded and many a times lack adequate school facilities, forcing the children into an unhealthy environs. The curriculum remains rigidly test-centric which leaves the children with no time and opportunity to attain the knowledge and skills needed to realize their full human potential (Kumar, 1998). This situation further minimises their chances of being able to claim their human rights in a democratic society. There is further opposition to this market approach from various quarters like teachers' forum of the U.S. The market approach ignores added values which are incalculable; also the commitment public service workers make especially in education sector will be missing (www.Icope.org). There is unanimity on the fact that provision of and access to education is a social good and something we cannot do away with if we want to work towards development, economic growth and poverty alleviation (Bangs, 2007).

The above discussion clearly shows why Indian education policies have failed to deliver and how the right to education will go a long way in fulfilling the aspirations of the poor. To develop an ideal education system based on the principles of human rights we require a concerted and focussed strategy covering the entire education sector. This would have a far-reaching benefit as education can be associated with other human rights and fundamental freedoms such as the right to work; playing major role in poverty eradication, the right to marry and have a family which will impact demographic positive changes, and the right to political participation highlighting importance of education for building all-inclusive societies (Alston and Bhuta, 2005).

The biggest reason for education to be human rights based will be the difference in age-based rights of children. To illustrate further, in India, the minimum school-leaving age is 14 years; minimum age of employment is 14 years; the minimum age for marriage varies and the minimum age of criminal responsibility is 12 years (Tomasevski, 2004). Children are not recognised as having an equal standing which can justify their claim to rights! Children are not in a position to do anything in case their rights are violated. And violations of right to education are continuously being committed by the governments with the rhetoric given that education is incompatible with the human rights. If education is for sale it will never reach the poor and they will continue to be denied of their right to education (GoI Report). A cursory analysis of Indian State education laws bring to light the fact that they are all based on the truancy model, penalising poor parents. Further, these laws do not guarantee compulsory education. And clearly it all goes to show where the root cause of sad affairs of education system lies. As the education system is not governed by uniform laws, is not based on human rights model, it has been violating the rights of millions of Indian children. The victims are left with no means to realize their other rights also. Continued violations and denials of rights go on to destabilise the society and unfortunately so human rights violations become biggest threat to humanity not only in India but the world over.

In the light of the above discussion, it would be appropriate to understand a human rights approach to policy-making in education. Ideally, the principles of human rights guiding the education system should include universality and inalienability, indivisibility, interdependence and interrelatedness, equality and nondiscrimination, participation and inclusion, empowerment and accountability and respect for the rule of law (Tomasevski, 2005).

A human rights approach would include following elements:

1. Evaluate claims of the rights-holders and corresponding obligations of duty-bearers. This will mean taking into consideration the claims, needs of the children on one hand and fixing responsibilities of the appropriate government/authority/teachers/parents/community. 
2. Develop capacity building. This will help children to be able to claim their rights and the government/dutybearers will also able to fulfil their obligations. Expansion of schools, strengthening health services, increasing employment options, programmes for poverty eradication, strengthening teacher-training, adequate remuneration to teachers, low cost housing for the poor, improving public distribution system etc. can be included here.

3. Provide for monitoring and evaluating outcomes. Such an education delivery process needs continuous monitoring, for example, introducing cumulative tests and semester system in place of year end exams.

4. Follow recommendations of the international human rights bodies (Aradhya and Kashyap, 2006). According to Asbjorn Eide, a three level typology of states' duties which can be used as a framework to evaluate all general human rights obligations of the state using this framework for education system will give a clear understanding of what a state/government is expected to ensure the right to education.

\section{The states' duties will be:}

1. To Respect. This will mean an enabling framework of legislation. The rules are to help the child and the parent and not to harass or deter them from access to education. Formalities preventing access to education like unending paperwork, proof of residence, birth certificate etc. must be done away with.

2. To Protect. This will mean that the state/government/authorities do not act to deprive the child of his/her right. Child labour for example would deprive the child of his/her right to education Just abolishing child labour will not do, the government has not been able to check it so far with half-hearted policy-making.

3. To Facilitate and Fulfil Human Rights (Aradhya and Kashyap, 2006). This will mean that the state/government takes upon itself to provide and fulfil human rights through maximising and strengthening peoples' access to education and optimising utilisation of resources. Some efforts like the NREGA (National Rural Employment Guarantee Act) scheme, PWD's low cost housing projects for the poor, Sulabh public pay and use toilets, health programmes like Pulse Polio, Neo-natal care for the mother and child can be mentioned here.

According to Katarina Tomasevski, only a human rights approach can effectively redress the issues of right to education, eliminate poverty as well as child labour as all are connected. The 4-A's scheme developed by her is the correct tool to assess right to education and structure the required framework. These are as following:

1. Availability. Education as a civil and political right makes government establish schools which respect freedom of and in education; education as a social and economic right will mean that the government has to ensure availability of free and compulsory education to all children; education as a cultural right will require that diversity be respected as well as protected and expressed through minority laws. In simple language education is free and government-funded; there are enough schools with proper infrastructure and there are qualified and trained teachers to ensure and support education delivery.

2. Accessibility. This will mean that the government must work towards eliminating gender and caste discriminations to ensure equal realisation of all human rights, that positive steps are taken to reach the most poor and marginalised.

3. Acceptability. This means that minimum guarantee for quality of education is given, fixed, monitored and enforced by the government. These may include content of education, prioritising language of instruction, prohibition of corporal punishment, safety of school premises, professional teachers etc.

4. Adaptability. This means that education and schools can evolve with changing times and requirements of the society. Also this means that every individual's needs are catered to according to Convention on the Rights of the Child (CRC) and can be adapted at local levels to suit diverse needs (Alston and Bhuta, 2005).

\section{Suggested Policy Options}

All of the above theoretical approaches are not definitive but do help to assess the rights issues. Now that the right to education has been declared a fundamental right to children, it is logical to shape the policy according to the human rights approach. Incorporating this theoretical approach, the policy options are:

- Amend the age-related clause in the right to education act and include 0-6 and 14-18 years.

- Amend labour laws.

- Establish integrated schools: pre-school to 12th standard according to the number of school-age children.

- Adopt the Common School System in letter and spirit.

- Incorporate skills development/vocational subjects in schools.

- Adopt an integrated approach to school education, adult education, youth development, workforce training and teacher training to fulfil 21 st century requirements. 
- Develop capacity of district administrative machinery and schools.

- Involve parents and community in school administration.

- Promote active interface of schools with corporate bodies and businesses.

\section{Conclusions}

A year after the RTE coming into effect there is no visible and marked change in the status of schools according to the surveys, interviews and observations carried out in selected schools. Schools were randomly selected and the sample was a mix of government, government-aided, private, convents and Kendriya Vidyalayas. According to general observation the government schools fare badly in all areas such as buildings, water and electricity, toilet facilities, discipline, cleanliness, education-delivery and motivation level of the teachers as well as the students. Pune being a metropolitan city, at least electricity and drinking water facilities are available in almost $100 \%$ of the schools whereas in Guwahati these facilities are not available in many cases. The student-teacher ratio exceeds 55:1 in most of the schools. Both in Pune and Guwahati, the awareness level regarding the RTE Act is low among the teachers.

The analysis of Indian Education system spells out the urgent need for a complete and new orientation. The Right to Education Act, 2009, brings forth the solace that some if not all provisions have been made as per the international human rights instruments. It is a wishful thinking that more can be done at the implementation level. Half of the work has been done with the legislation of the Right to Education Act, 2009, whereas a lot more is yet to be done to ensure its proper implementation. The positive provisions of the right to education policy, if implemented in the true sense of the term at the ground level, the schools, can have positive impact on enrolment and retention. But the negative provisions will limit the benefits of the Right to Education. The former HRD minister, Kapil Sibal, stated that at least five more years are required to implement all the provisions of Right to Education. Indian public and the NGOs have been very vocal in pursuing the campaign for Right to Education at the policy-making level but have to do more when it comes to work at and realise Right to Education. This will check further violations of child rights. At local levels the communities need to do an in-depth analysis to be able to make strategies, build partnerships, mobilise people, increase awareness, communicate with government, media and the NGO's.

\section{References}

[1]. Aggarwal JC, 2005, Recent Developments and Trends in Education, Shipra Publications, Delhi

[2]. Aggarwal JC, 2011, Development and Planning of Modern Education, Vikas Publishing House, New Delhi, p 453

[3]. A Human Rights- Based Application to Education for All, UN Educational, Scientific and Cultural Organisation, 2007

[4]. Aikara J, 2004, Educational, Sociological Perspective, Rawat Publications, New Delhi

[5]. Alston P and Bhuta N, 2005, Human Rights and Public Goods :Education as a Fundamental Right in India, Centre For Human Rights and Global Justice, Working Paper, Economic, Social and Cultural Rights Series, No.5

[6]. Annual report of Special Rapporteur on RTE, Commission on Human Rights, 2001, 57th Session, www.un.org

[7]. Aradhya N and Kashyap A,2006, The Fundamentals: Right to Education in India, Centre for Child and the Law, National Law School of India University, Bangalore

[8]. Bangs J, 2007, Education: A Fundamental Human Right, National Union of Teachers, OECD Forum

[9]. Berger E, (2003), The Right to Education under the South African Constitution, Columbia Law Review, Vol.103, No.3, pp.614-661

[10]. Berger E, (2003), p 626

[11]. Dreze J and Sen A, 1996, Economic Development and Social Opportunity, New Delhi, Oxford University Press

[12]. Education is a Human Right Campaign, Icope, Independent Commission on Public Education, www.Icope.org

[13]. Guha R, Hindustan Times, 31 Mar 2005

[14]. Gershberg AI, (1999), Education De-centralization Processes in Mexico and Nicaragua: Legislative versus Ministry-Led Reform Strategies, Comparative Education, Vol.35, No.1, Taylor and Francis, pp.63-80

[15]. Indian Government Report under Convention on Rights of the Child

[16]. Jain LC, 2008, Right to Education, Yojana

[17]. Kuenning MA and Amin S, 2005, School Incentive Programmes and Children's Activities: Case of Bangladesh, Comparative Education Review

[18]. Kumar R, 2006, State, Class and Critical framework of Praxis: The Missing Link in Indian Educational Debates, Journal for Critical Educational Policy Studies, Vol.4, No.2

[19]. Kumar K, 1998, Education and Society in Post -Independence India: Looking Towards the Future, Economic Political Weekly, Vol.33, No.23

[20]. Mehrotra S (1998), Education for All: Policy Lessons from High Achieving Countries, International Review of Education, Vol.44, No.5/6

[21]. Millan DS, ActionAid, available at http://www.right-to-education.org/node/233, (accessed on14 February 2009)

[22]. Right to Education: First Anniversary Report, Education World, May 2011.

[23]. RTE Project, http: Ilwww.right-to-education.org/node/233.

[24]. Singh R, 'Interpreting Census 2011', Education World, May 2011

[25]. Sripathi V and ThiruvengadamAK, 2004, Constitutional Amendment Making the Right to Education a Fundamental Right,International Journal of Constitutional Law

[26]. Sripati V and Thiruvengadam AK, 2004, p 148-158

[27]. Subbarao K and Raney L (1995), Social Gains from Female Education: A Cross-National Study, Economic Development and Cultural Change, Vol.44, No.1, The University of Chicago Press, pp.105-128

[28]. Taylor L, Action Aid,available at http://www.right-to-education.org/node/233, (accessed on14 February 2009)

[29]. The Independent, Sunday, 21 August, 2005, p 8

[30]. Tomasevski K, 2004, Manual on Rights-Based Education, Global Human Rights Requirement made Simple, UNESCO, Bangkok 
[31]. Tomasevski K, 2005, Has the Right to Education a Future Within the UN?ABehind the Scenes Account by the Special Rapporteur on Right to Education, 1998-2004, Human Rights Law Review ,Oxford University Press

[32]. Tomasevski K (2001), Removing Obstacles in the way of the Right to Education, RTE Primers No.1, SIDA, p15

[33]. Tomasevski K (2001), Free and compulsory education for all children: the gap between promise and performance, RTE Primers No.2, SIDA

MamtaViswanath is a research scholar at the department of Politics and Public Administration, University of Pune, Maharashtra, India. Her research interest lies in the areas of Public administration, Public Policy, Education policy, Human rights, Sustainability, Human resource development and Democracy. 